\title{
Cenozoic environmental changes along the East Antarctic continental margin inferred from regional seismic stratigraphy
}

\author{
G. L. Leitchenkov, ${ }^{1}$ Y. B. Guseva, ${ }^{2}$ and V. V. Gandyukhin ${ }^{2}$ \\ ${ }^{1}$ Institute for Geology and Mineral Resources of the World Ocean, 1, Angliysky Ave. 190121, St.-Petersburg, Russia (german_1@mail.ru) \\ ${ }^{2}$ Polar Marine Geosurvey Expedition, 24, Pobedy St., 189510, Lomonosov, St.-Petersburg, Russia (antarctida@peterlink.ru)
}

\begin{abstract}
We interpret $40000 \mathrm{~km}$ of multichannel seismic reflection lines collected by the Russian Antarctic Expedition along the East Antarctic continental margin between $32^{\circ} \mathrm{E}$ and $115^{\circ} \mathrm{E}$, and present a revised seismic stratigraphic model for depositional paleoenvironments of the region. Variations in acoustic facies characteristics observed across major seismic horizons are correlated with paleoenvironmental changes deciphered from Antarctic drilling data and deep-sea "proxy" records. Our results, as well as other studies, indicate that the East Antarctic margin was glaciated at different times. Glacial ice first reached the western Wilkes Land margin in the Middle Eocene and then advanced onto most parts of the East Antarctic continental shelf during the earliest Oligocene. During the Neogene, bottom currents deposited a variety of drift deposits along the margin.
\end{abstract}

Citation: Leitchenkov, G. L., Y. B. Guseva, V. V. Gandyukhin (2007), Cenozoic environmental changes along the East Antarctic continental margin inferred from regional seismic stratigraphy, in Antarctica: A Keystone in a Changing World - Online Proceedings of the $10^{\text {th }}$ ISAES, edited by A. K. Cooper and C. R. Raymond et al., USGS Open-File Report 2007-1047, Short Research Paper 005, 4 p.; doi:10.3133/of2007-1047.srp005.

\section{Introduction}

Seismic stratigraphy is a key tool in helping to decipher paleoceanographic conditions and the history of ice sheet growth along the East Antarctic continental margin (EAM). Many seismic stratigraphic studies have been done in the region (e.g. DeSantis et al., 2003; Close et al., 2007), and our extensive network of seismic data (Fig. 1) is linked in part to these studies.

This paper discusses the succession and timing of ice sheet advances to the continental margin during the early stage of glaciation and into the early Neogene, interpreted from the $\sim 40000 \mathrm{~km}$ of multichannel seismic (MCS) data acquired on the continental slope and rise of the EAM from $32^{\circ} \mathrm{E}$ to $115^{\circ} \mathrm{E}$ by the Russian Antarctic Expeditions (RAE; Fig 1). We also discuss reasons for some structural and geomorphic changes observed in seismic records.

\section{Seismic stratigraphy}

Our seismic stratigraphic model has been constructed for the deep water areas of the EAM using all RAE MCS lines. We map five major seismic horizons across the studied region. These horizons are generally highamplitude continuous reflectors that separate seismic units with different internal reflection patterns. The horizons are developed widely on the EAM and are likely to be caused by major changes in the depositional environment. As such, they probably reflect changes in lithology, with or without breaks in sedimentation, and are therefore largely unconformities and disconformities. The horizons are numbered up-section from " 1 " to "5", with letter prefixes to denote their different geographic locations and tectonic settings (Fig. 2). Two regions are delimited in this context: I) Cosmonaut Sea, Cooperation Sea and Davis Sea (horizon prefix 'CS'); and II) Wilkes Land margin (horizon prefix 'WL'). Region I developed as India separated from Antarctica, while Region II developed as Australia separated from Antarctica.

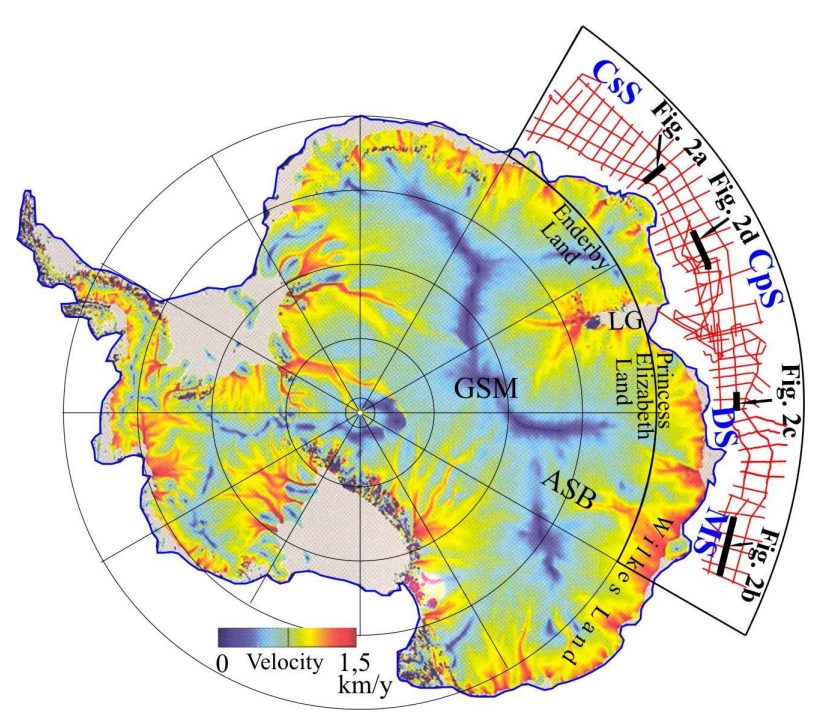

Figure 1. Study area and location of seismic lines used in this paper. Bold lines show locations of illustrated seismic profiles with figure numbers. Colour image on Antarctica shows present-day ice velocities (after Rignot and Thomas, 2002). ASB - Aurora Subglacial Basin, GSM Gamburtsev Subglacial Mountains, LB - Lambert Graben, CsS - Cosmonaut Sea, CpS - Cooperation Sea, DS - Davis Sea, MS - Mawson Sea.

We interpret the oldest regional horizons CS1 and WL1 as correlating with asynchronous continental breakup that occurred in the Early Cretaceous between Greater India and East Antarctica (Region I, about $132.5 \mathrm{Ma}$; e.g. Powell et al., 1988) and in Late Cretaceous between Australia and East Antarctica (Region II, about $83 \mathrm{Ma}$; Sayers et al., 2001; Leitchenkov et al., this volume). Horizon "2" is mapped only on the EAM from the Cosmonaut Sea to the Davis Sea (CS2) and is absent in the Mawson Sea. We estimate the age of CS2 to be not older than the middle Early Cretaceous, based on its onlap 
of magnetic-anomaly dated oceanic crust. The overlying horizons " 3 ", "4" and "5" are tied between lines throughout our study area. We believe that they are isochronous boundaries that likely denote significant environmental and oceanographic changes in the Southern Ocean. Horizon " 3 " onlaps the early Eocene oceanic crust (magnetic anomalies 22-24) off western Wilkes Land (Close et al., 2007; Leitchenkov et. al., this volume) and so is not older than that age. Younger horizons do not onlap oceanic basement in the study region.

The units below horizon " 3 " are generally characterized by subparallel continuous to discontinuous reflectors (Fig. 2). However, on the Enderby Land margin, the unit between CS2 and CS3 instead comprises two large lens-shaped, poorly-stratified sediment mounds that thin both upslope and down-slope (Fig. 2a and 3). Similar but smaller sediment mounds are also documented in the western Mawson Sea (east of Bruce Bank) between WL1 and WL3 and in the eastern Davis Sea (west of Bruce Bank) between CS3 and CS4 (Fig. 3). Horizon " 3 " marks changes in seismic reflection patterns in some parts of the EAM. On the Enderby Land margin, lens-shaped sediment mounds continued to develop in the section above CS3 and are terminated by CS4. They have partly overlapped older (CS2-CS3) mounds and are larger than those mounds (Fig. 3).

A prominent seismic facies change occurs across horizon WL3 in the Mawson Sea. The strata above this horizon show a spatially isometric lobe of semitransparent strata (Figs $2 \mathrm{~b}$ and 3), lenticular bodies with chaotic internal reflectors, and small channels. WL3 correlates with horizons WL-U3 of DeSantis et al. (2004) on the eastern Wilkes Land margin, and "eoc" of Close et al. (2007), identified along the length of the Wilkes Land margin.

Horizon "4" marks the initiation of buried channellevee systems throughout our study region except in the area off Princess Elizabeth Land where such systems are not observed (Fig. 2c). In the western Cooperation Sea, horizon CS4 underlies semi-transparent strata similar to those recognized in the Mawson Sea above horizon WL3 (Figs 2d and 3). Horizon CS4 corresponds to the reflector P1 identified by Kuvaas and Leitchenkov (1992) in the Cooperation Sea and can probably be correlated with WLU4 of DeSantis et al. (2003) on the eastern Wilkes Land margin. This horizon also correlates with "regional reflector CS-4" recognized by Kuvaas et al. (2005) in the Cosmonaut Sea at the "stratigraphic level at which channelized activity" is initiated.

Horizon " 5 " is the shallowest horizon that can be mapped regionally. The section above this horizon is characterized by the presence of numerous variably shaped mounds and fields of wavy reflectors. The fields of wavy reflectors lie parallel to the channel-levee systems and parallel to the margin demonstrating apparent up-slope and eastward along-slope migration (Fig. 3). Above horizon " 5 ", channels are more abundant than they are in the underlying sequence, except on the Princess Elizabeth margin where channels are poorly developed. Horizon " 5 " correlates with reflector P2 of Kuvaas and Leitchenkov (1992) in the Cooperation Sea and tentatively with WL-U5 on the eastern Wilkes Land margin of DeSantis et al. (2003).

\section{Discussion}

The uniform parallel-bedded seismic stratigraphy of the early post-breakup units in Region I suggest to us that hemipelagic sedimentation dominated along this part of the EAM continental rise prior to horizon "4" time, except where mounded structures are present (Fig. 3). Kuvaas et al. (2005) interpreted large lens-shaped mounds on the Enderby Land margin as slope-plastered drifts formed under the influence of broad non-focused bottom currents flowing westward along the continental rise.

The change in seismic reflection character across horizon WL3 in the Mawson Sea marks the initiation of down-slope sedimentation processes. These are proposed to have been responsible for the formation of channellevee systems and the deposition of semitransparent strata and lenticular bodies that we interpret as sheeted turbidites and debris-flows, respectively (Fig. 2b). A similar change is also seen across CS4 in the Cosmonaut, Cooperation and eastern Davis Seas and across CS5 off Princess Elizabeth Land (Fig. 2a, 2d, 2c). Triggering of active down-slope processes on the EAM may be explained by the arrival of the ice sheet at the edge of the continental shelf and the resultant supply of a large amount of terrigenous sediments to the continental slope and rise (e.g. Kuvaas and Leitchenkov, 1992).

The occurrence of down-slope sedimentary features (predominantly turbidity channels and levees) at different stratigraphic levels leads us to conclude that the EAM was glaciated at different times. We propose that the ice sheet first reached the shelf edge in the Mawson Sea at the time of WL3, as that is the deepest stratigraphic level at which stratal facies and geometries change significantly. Elsewhere in our study region, the parallelbedded seismic character between horizons " 3 " and " 4 " (Fig. 2) indicates hemipelagic sedimentation that is not influenced by glaciation. Widespread development of channel-levee systems above horizon " 4 " denotes significant expansion of the East Antarctic ice sheet. The time of the first ice expansion onto the shelf has been established as the earliest Oligocene (about $34 \mathrm{Ma}$, Cooper and O'Brien, 2004) in Prydz Bay based on ODP core data. This advance coincides with continental-scale Antarctic glaciation inferred from deep-sea "proxy" records (Zachos et al. 2001; Miller et al., 2006).

The age of horizon " 5 " can be estimated as about 24 Ma based on the recovery of 22 Ma-old sediments some $200 \mathrm{~m}$ above this horizon at ODP Site 1165 and on the downward continuation of the bottomhole sedimentation rate of $100 \mathrm{~m} / \mathrm{m}$.y. (Cooper and O'Brien, 2004). Using age constraints defined for horizons " 4 " and " 5 " and 

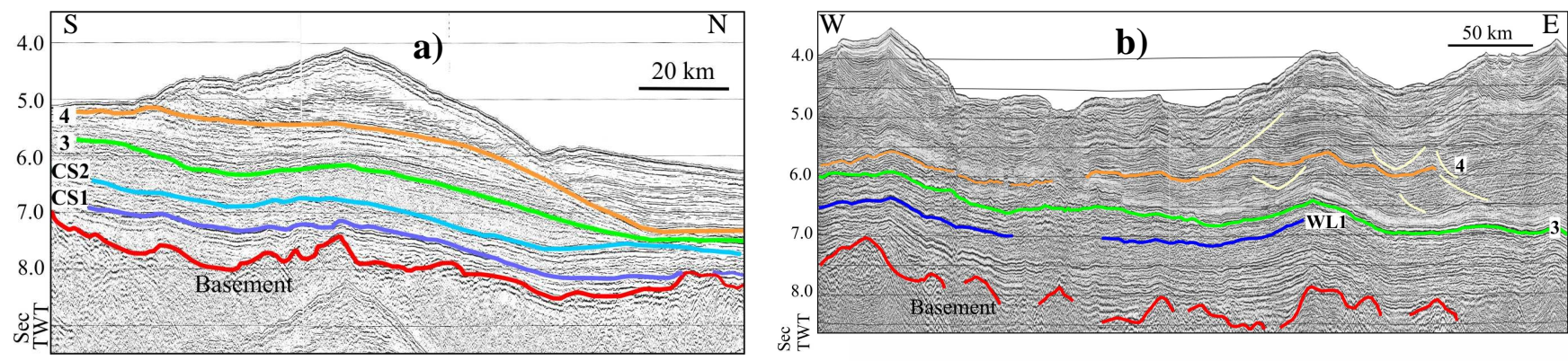

Figure 2. Seismic stratigraphy examples of the deep-water sedimentary section on the East Antarctic margin. a) Cosmonaut Sea; b) eastern Mawson Sea; c) Davis Sea; d) Cooperation Sea.
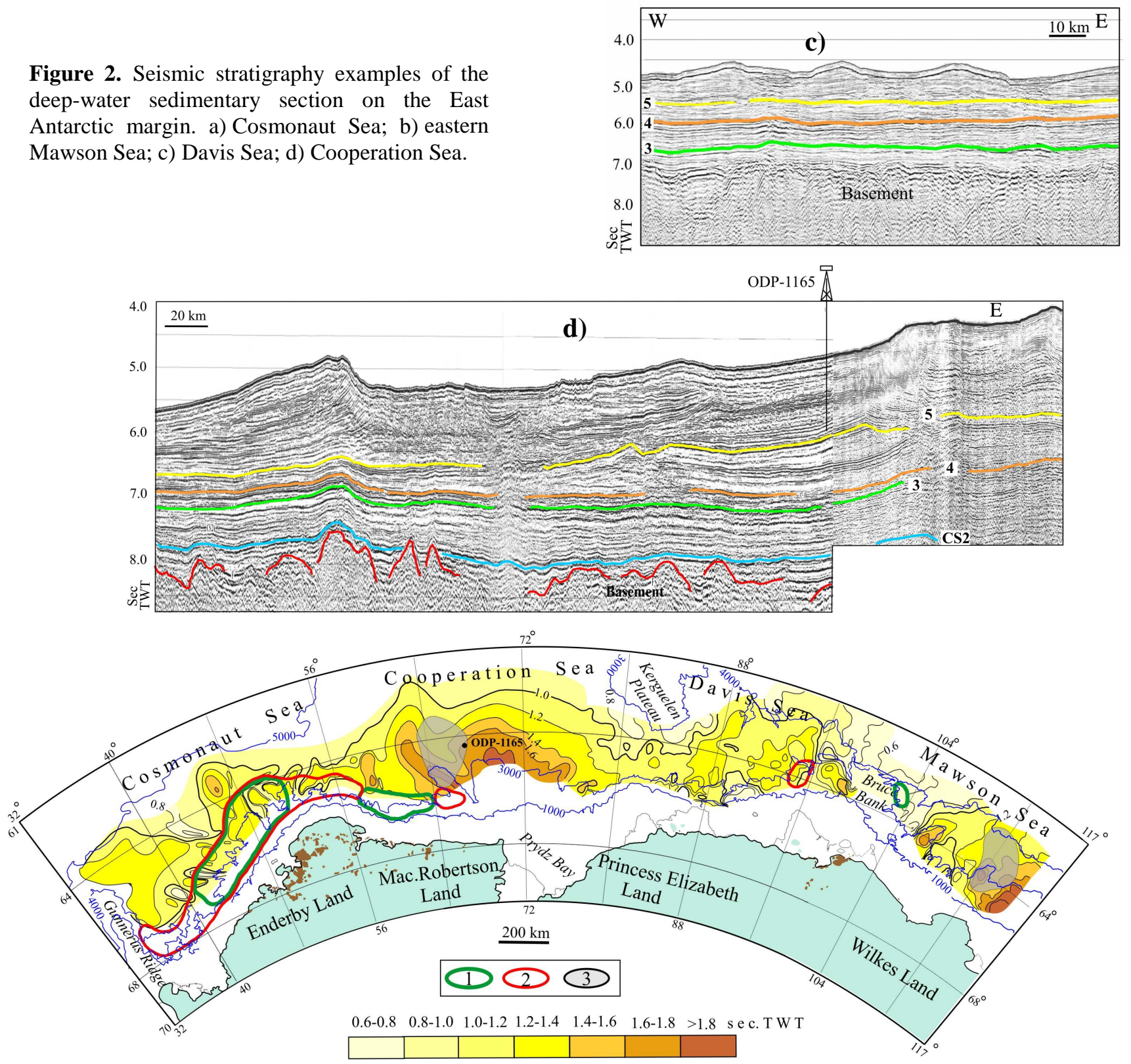

Figure 3. Sedimentary and morphologic features of the study area. Blue lines are isobaths. Colour shading and black lines show thickness (seconds, TWT) of post-Early Oligocene glacial-marine strata above horizon "4". Legend: 1 sediment mounds deposited between CS2 and CS3 (Enderby Land margin), and between WL1 and WL3 (western Mawson Sea); 2 - sediment mounds deposited between CS3 and CS4; 3 - lobes of semi-transparent strata deposited between WL3 and WL4 (eastern Mawson Sea), and between CS4 and CS5 (western Cooperation Sea). 
thickness values for strata between them, the maximum rate of Oligocene glacial marine sedimentation in the western Cooperation Sea is calculated to be 90-100 $\mathrm{m} / \mathrm{m}$.y., a rate that is almost twice that estimated here for other parts of Region I. Gravity-driven sedimentation is not observed on the slope off Princess Elizabeth below CS5, indicating a low-energy environment. This suggests that this margin was not glaciated before the Early Miocene. Alternatively, the ice velocity on that margin was low and the volume of sediment was insufficient to trigger gravity-driven sedimentation.

The time of earliest arrival of the ice sheet to the Mawson Sea, as marked by horizon WL3, is not known because there are no nearby drill cores which sampled this horizon (Fig. 2d). From our seismic stratigraphic model presented here, we postulate that the age of this event is between the early Eocene (the age derived from correlation with the dated ocean crust) and the earliest Oligocene (the age of horizon “4”). Tripaty et al. (2005) argue that onset of large glaciation in both polar regions was at around $42 \mathrm{Ma}$, with smaller glaciations at 39 and $36 \mathrm{Ma}$, based on detailed studies of the $\mathrm{CCD}, \mathrm{CO}_{2}$ atmospheric concentration, and stable isotope records in tropical parts of oceans. The onset of glaciation at $42 \mathrm{Ma}$ is also inferred from a prominent sea level fall of about $75 \mathrm{~m}$ amplitude estimated by Miller et al. (2006). We assume that at $42 \mathrm{Ma}$, glaciers could reach the western Wilkes Land margin flowing from the Gamburtsev Subglacial Mountains through the deep valley of the Aurora Subglacial Basin (Figs 1 and 3). Using our suggested ages for horizons " 3 " and "4", the maximum rate of Middle-Late Eocene sedimentation in the eastern Mawson Sea is more than $150-160 \mathrm{~m} / \mathrm{m}$.y. This is two to three times greater than on the other parts of the EAM where hemipelagic sedimentation dominated.

Multiform sediment mounds and zones of wavy reflectors (mud waves) above horizon " 5 " are interpreted as contourite drifts that mostly formed as a result of interaction between active along-slope bottom currents and down-slope turbidite flows (Kuvaas et al., 2005). Thus, widespread development of current-controlled drifts above horizon " 5 " indicates that since the Early Miocene, west-flowing bottom currents have been prevalent possibly due to active Antarctic Bottom Water formation.

We infer that the thickness of strata deposited during post-Early Oligocene glaciations generally reflects the averaged energy of depositional environments (Fig. 3). The thickest sediments (up to $2.0 \mathrm{~s}$ two-way time, TWT) and inferred highest energy are seen in the Cooperation Sea and the eastern Mawson Sea, in comparison with 1.0 $-1.3 \mathrm{~s}$ TWT thick sediments in other parts of our study area (Fig. 3). The areas with the thickest post-Early Oligocene strata correlate with places where present-day ice discharge is highest, such as via the Lambert Graben to Prydz Bay and via the Aurora Basin to the eastern Mawson Sea (Fig. 1; Rignot and Thomas, 2002). The correlation points to high ice (and sediment) flux in the same areas since the Early Oligocene.

\section{Summary}

We propose a revised seismic stratigraphic model for the EAM, in which horizons " 1 " and " 2 " are due to Gondwana breakup and early post-breakup events, and horizons " 3 ", "4" and "5" are isochronous surfaces related to paleoenvironmental transitions. Systematic up-section changes in stratal facies and geometries lead us to suggest: 1) the ice sheet first reached the margin in the Middle-Late Eocene, discharging to the Mawson Sea; 2) continental-scale glaciation in the Early Oligocene led to widespread development of channel-levee systems on the EAM, except on the Elizabeth Land; 3) westward-flowing bottom currents prevailed on the EAM from the Early to Middle Miocene and initiated building a variety of contourite drifts; and 4) rapid ice discharge and high rates of glaciogenic sedimentation were focused toward the western Cooperation Sea and the Mawson Sea..

Acknowledgements. We are grateful to Alan Cooper, Yngve Kristoffersen, Phil O'Brien and Howard Stagg whose constructive comments were welcome.

\section{References}

Close, D. I., H. M. J. Stagg, P. E. O'Brien (2007), Seismic stratigraphy and sediment distribution on the Wilkes Land and Terre Adélie margins, East Antarctica, Marine Geology, 239, 33-57.

Cooper, A. K. and P. E. O'Brien (2004), Leg 188 synthesis: transitions in the glacial history of the Prydz Bay region, East Antarctica, from ODP drilling, Proc. ODP, Sci. Results, edited by A. K. Cooper, P. E. O'Brien and C. Richter, 188, 1-42.

DeSantis, L., G. Brancolini, and F. Donda (2003), Seismo-stratigraphic analysis of the Wilkes Land continental margin (East Antarctica): influence of glacially-driven processes on the Cenozoic deposition, Deep-Sea Research II, 50, 8-9, 1563-1594.

Leitchenkov G. L., V. V. Gandyukhin, Yu.B. Guseva (2007), Crustal structure and evolution of the Mawson Sea (western Wilkes Land margin, East Antarcuca), this volume.

Kuvaas, B., and G. Leitchenkov (1992), Glaciomarine turbidite and current-controlled deposits in Prydz Bay, Antarctica, Marine Geology, $108,365-381$.

Kuvaas, B., Y. Kristoffersen, J. Guseva, G. Leitchenkov, V. Gandjukhin, O. Lovas, M. Sand, and H. Brekke (2005), Interplay of turbidite and contourite deposition along the Cosmonaut Sea/Enderby Land margin, East Antarctica, Marine Geology, 217, 143-159.

Miller, K. G., M. A. Kominz, J. V. Browning, J. D. Wright, G. S. Mountain, M. E. Katz, P. J. Sugarman, B. S. Cramer, N. ChristieBlick, and S. F. Pekar (2006), The Phanerozoic record of global sealevel change, Science, 310, 1293-1298.

Powell, C. A., S. R. Roots, and J. J. Veevers (1988), Pre-breakup continental extension in East Gondwanaland and early opening of the eastern Indian Ocean, Tectonophysics, 155, 261-283.

Rignot, E. and R. H. Thomas (2002), Mass balance of polar ice sheets, Science, 297, 1502-1506

Sayers, J., P. Symonds, N. G. Direen, and G. Bernardel (2001), Nature of the continent-ocean transition on the non-volcanic rifted margin of the central Great Australian Bight, in Non-Volcanic Rifting of Continental Margins: A Comparison of Evidence from Land and Sea, edited by R. C. L. Wilson, R. B., Whitmarsh, B. Taylor, and N. Froitzheim, Geol. Soc. London, Spec. Publ., 187, 51-77.

Tripati, A., J. Backman, H. Elderfield, and P. Ferretti (2005), Eocene bipolar glaciation associated with global carbon cycle changes, Nature, 436, 341-346.

Zachos, J., M. Pagani, L. Sloan, E. Thomas, and K. Billups (2001), Trends, rhythms, and aberrations in global climate 65 Ma to present, Science, 292, 686-693. 